\title{
Electrophoretic Production of "Reactive" Axon Swellings in Vitro and their Histochemical Properties*
}

\author{
By \\ Reinhard L. Friede \\ With 5 Figures in the Text
}

(Received March 12, 1963)

\section{Introduction}

Extensive experimental evidence for a proximo-distal convection of axoplasm was collected by WEIss ${ }^{40-46}$. In addition, evidence has been gathered for the convection, along axons, of a number of specific substances (GERARD ${ }^{10}$ ) such as cholinesterase $11,12,21-23,34,38,49$, oxidative enzymes ${ }^{6}$, phosphoproteins ${ }^{32}$, phosphorus $^{27-29}$, phospholipids ${ }^{25}$, and amino acids ${ }^{5,18,39}$. While most of the investigations supported the concept of proximo-distal convection of axoplasm, a few others 19,20 did not find supporting evidence for the hypothesis.

The forces responsible for the convection of axoplasm along axons are not understood. Hypotheses have included the "vis a tergo" or pressure produced by the continuous synthesis of cytoplasm by the cell ${ }^{47}$, the pulse wave ${ }^{40}$, and a peristaltic activity of the axon ${ }^{43,46}$. The data available still justifies OcHs' ${ }^{28}$ remark that "the mechanism of axoplasmic flow remains an intriguing mystery".

The present investigation provided experimental data in support of the concept that electrophoresis may be responsible for axoplasmic convection. The typical "reactive" or "degenerative" axonal changes that are known to develop in transected fibers were produced in vitro by electrophoresis of axoplasm. Various substances subject to electrophoretic convection were identified by histochemical methods. Enzyme histochemical techniques and silver stains were used for routine evaluation. The routine use of histochemistry merely reflected the basic orientation of this laboratory and the dependability that these methods had in our hands. Histochemical and silver methods were equally satisfactory for interpretation and evaluation of the sections. Electrophoretic convection of substances along nerves has been considered by YUIEN and SATO ${ }^{48}$ and by WeIss, WANG, TAYLOR, and EDDS ${ }^{46}$, but no substantial evidence for this concept has been produced as yet.

\section{Material and Methods}

82 samples of cat sciatic nerves (about $5 \mathrm{~cm}$ long) were used for the experiments in Part I; some additional material of rat sciatic nerves, cow spinal nerves, and rat and cat spinal cord was also investigated. Cats were killed with pentothal anesthesia and the sciatic nerves were removed immediately, avoiding any mechanical insult, such as pressure or stretching, of the nerves. Some nerves were used immediately upon removal, others were stored in saline for several hours before the experiment; such storage had no effect on the results. Immediately

* This investigation was supported by U.S. Public Health Service, Grant No. B-3250. 
before current was applied, most of the nerves were constricted with a silk ligature to approximately one-half of their diameter; others received multiple blows with a blunt edge along the entire course of the nerve. A longitudinal current ranging from 5-140 volts was applied to the nerves for periods of 15 min to $6 \mathrm{hrs}$. For standard experiments, $90-110$ volts with a current of approximately $10 \mathrm{~m} \mathrm{Amp}$ were used for $2 \mathrm{hrs}$. During the experiment, the current was monitored and adjustments were made to correct changes of the current due to polarization of the electrodes. Contact was made by immersing about 1-2 mm of the nerve stumps in small jars of Ringer's solution, into which silver wire electrodes were placed. Migration of metal ions into the nerve tissue was hindered by keeping a distance of several centimeters between the electrodes and the immersed stump of the nerve. During exposure to current, the nerve rested in a moist chamber. If the experiment was done at room temperature, there was considerable heat production in the tissue; the earliest sign of heating was inactivation of enzyme activity in the histochemical preparations. Inactivation of enzymes could be prevented by cooling the nerve on a glass tube through which water of $4^{\circ} \mathrm{C}$ was circulated. With this arrangement, heat inactivation of enzymes occurred only at the extreme upper limits of the currents indicated above.

\section{Histological and Histochemical Methods}

All nerves were cut longitudinally, parallel to the course of the fibers. For routine evaluation, nerves were fixed in cold formalin over night. After frozen sections were cut, the remainder of the nerve was dehydrated and embedded in paraffin. $30 \mu$ frozen sections were incubated in media for DPN-diaphorase and lactic dehydrogenase. Methods for these enzymes were quantitatively reliable when formalin-fixed tissue was use ${ }^{9} .30 \mu$ sections of unfixed tissue were incubated for succinic dehydrogenase, cytochrome oxidase, isocitric dehydrogenase, malic dehydrogenase, glycero-phosphate dehydrogenase, glucose-6-phosphate dehydrogenase, 6-phosphogluconate dehydrogenase, glutamate dehydrogenase, alcohol dehydrogenase, and TPN-diaphorase. The media and incubation conditions were essentially as given in PEARSE ${ }^{30}$; however, several critical differences of methodology have been described in a separate publication ${ }^{9}$. Acid and alkaline phosphatases were demonstrated in $30 \mu$ formalin-fixed sections, using azo-coupling methods ${ }^{30}$. All incubations were done in a constant temperature shaker water bath.

$10 \mu$ paraffin sections were routinely stained with Bodian's silver method. Paraffin sections were also used for the periodic acid-Schiff reaction; the alloxan-Schiff reaction (for proteins), NoveLLI's ${ }^{26}$ stain for mitochondria (using both formalin and Regaud-fixed material), and the chromalum gallocyanin stain with ribonuclease controls. Frozen sections of formalin-fixed tissue, 10 and $30 \mu$, were stained with Sudan-black.

The material used for Part II is being described with the results, since this facilitates interpretation; processing of this material was the same as described above.

\section{Observations}

\section{Part I: In Vitro Experiments on normal Nerves}

Production of Axon Swellings by Electrophoresis. Exposure of nerves to a longitudinal current produced axon swellings which were indistinguishable from the reactive changes seen in damaged fibers in neuropathological and experimental material. There were several characteristic types of morphological changes, but the frequent transitions between these types implied a quantitative rather than qualitative difference. A thickening and cork-screw-shaped or varicose contortion of the axon (Fig. 1 a and b) was considered as a slight alteration. Such varicose portions were seen both at the end of severed fibers (Fig.1 c) or as a local, confined deformity of the axons (Fig $1 \mathrm{a}$ and $\mathrm{b}$ ). If the axon was interrupted, there was usually a progressive thickening toward the stump (Fig.1 $\mathrm{c}$ and d), often with additional beading of the most distal portion (Fig. 1 c). Local cylindrical, sausage shaped, or fusiforme inflations of axons (without interruption of their continuity) were less frequent (Fig. $1 \mathrm{~d}$ ). More severe changes were characterized by fewer varicose deformations and more extensive swellings in which the stumps of axons were ovoid, club-shaped (Fig. 1e and f), or drop-shaped swellings (Fig.2a). 
These experimentally produced changes were indistinguishable from the reactive changes of damaged axons found in neuropathological or experimental material of central tracts or peripheral nerves as described by CAJAL ${ }^{4}$.

The Significance of Tissue Injury. The production of axon swellings depended on how much the fibers had been damaged before being subjected to current. If the utmost care was taken to avoid any mechanical insult to the nerves, very few, if any axon swellings developed. A decrease of the enzyme reaction was observed in such nerves, probably because of convection of axoplasm out of the nerve into the contact fluids. If a ligature was applied as described in

a

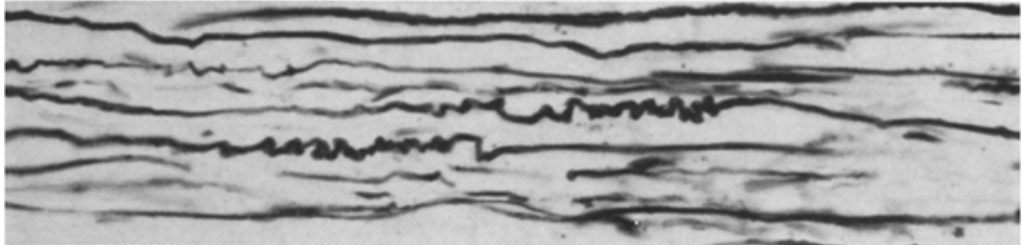

b
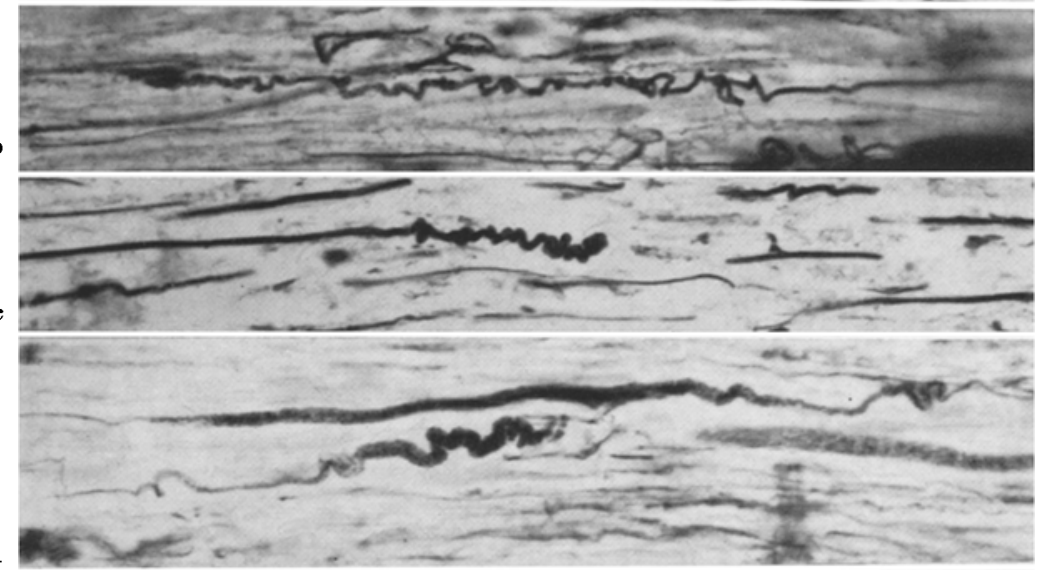

d

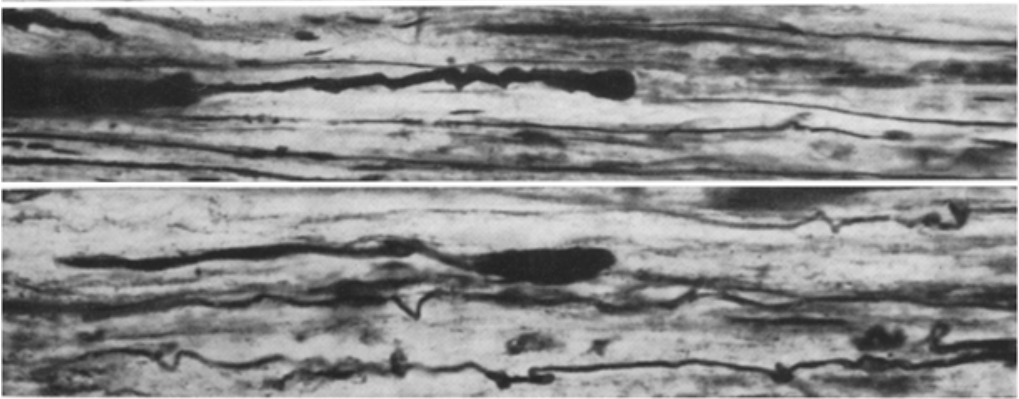

Fig. 1a-f. Electrophoretically produced axon swelling as shown by Bodian's silver stain (a, $c$, e) and the histochemical reaction for DPN-diaphorase $(b, d, f)$; $a$ and $b$ show typical varicose or corkscrew-shaped deformities: $c$ and $d$ more advanced swelling, and e and $f$ typical club-shaped térininal formations, $30 \mu 200 \times$

Material and Methods, axon swellings were found on both sides of the constriction. Production of swelling seemed to depend on the extent of damage caused by manipulating the nerve rather than the actual compression by the ligature. This interpretation was confirmed by application of multiple rough blows along the entire length of the nerve. Such nerves showed abundant axon swellings throughout their length. There was direct evidence of the mechanical injury to the fibres in adjacent Sudan-black stained seetions in which fragmented myelin sheaths were clearly demonstrated in regions in which axon swellings were found.

Time-Force Relationship in the Formation of Axon Swellings. Application of 100 volts for $1-2 \mathrm{hrs}$ produced extensive axon swellings. The production of swellings depended both on 
sufficient current and exposure time. With a constant exposure time of $2 \mathrm{hrs}$, the number and the extent of axon changes decreased with decreasing voltage; controls without current were always negative. Short exposure to $80-100$ volts for about $10 \mathrm{~min}$ did not produce swellings.

Since we routinely used the demonstration of enzymes for interpreting our results, the upper limit of voltage that could be used (approximately 120 volts) was determined by that which did not produce heat destruction of enzyme activity. However, the production of swellings was independent of heat inactivation of enzyme. After frozen sections had been cut for enzyme studies, the remainder of the nerve was embedded in paraffin, and sections stained with Bodian's silver method showed typical axon swelling in the portion of the nerve where DPN-diaphorase had been destroyed by heat.

An interesting observation in nerves in which some enzyme had been heat destroyed was that the enzyme was destroyed much earlier in Schwann cells than in axons. Such specimens showed enzyme reaction selectively in axons (Fig. 3a). This was considered an indication that much more current flowed through the perineural spaces than through axons. Also, there was probably an insulating effect of the sheaths.

Directions of Electrophoretic Convection. The direction of electrophoretic convection was indicated by the rounded head of the clubs or by progressive increase of axonal diameter.

a

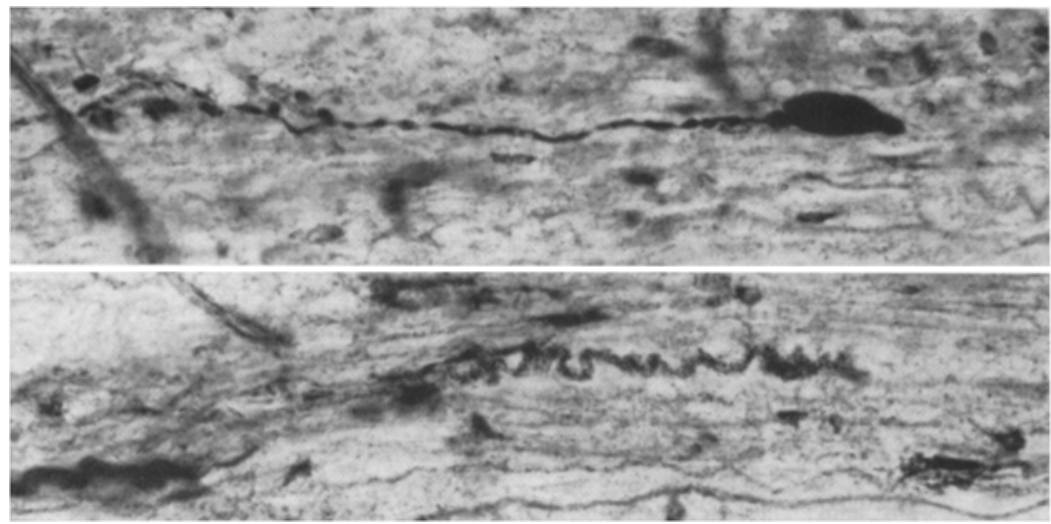

Fig. 2a and b. Typical axons swellings in fiber tracts of the spinal cord, produced by electrophoresis. DPN-diaphorase reaction, $30 \mu 200 \times$

Anodes and cathodes were carefully tagged on the histological preparations. There seemed to be a prevalence of convection toward the anode; however, in other fibers of the same nerve, the convection was opposite. Occasionally, clubs, headed in opposite directions, were seen adjacent to each other. Although the majority of axonal swellings were found in the vicinity of the ligatures, not all of them headed toward the constriction. There was, however, never any suggestion of convection of axoplasm in opposite directions in one given fiber. These observations suggested that electrophoretic convection of axoplasm may be in opposite directions in various types of fibers. We would like to reserve the full discussion of these observations for a later phase of this project.

Axon Swellings in Central Tracts. Seven spinal cords (cats) were exposed to a longitudinal current in the same way as that done for sciatic nerves. In these specimens, the same types and shapes of axonal swellings were produced (Fig. $2 a$ and $b$ ) as described above. The only difference from sciatic nerves was that fewer swellings were seen in cords, probably because it was more difficult to inflict an equal, predetermined amount of mechanical injury.

Histochemical Properties of Electrophoretic Axon Swellings. There was a marked reaction for the following enzymes in the axon swellings: DPN-diaphorase (used routinely for almost all the specimens of this series, Fig. $1 \mathrm{~b}, \mathbf{d}$ and $\mathrm{f}$ ), and lactic dehydrogenase (which gave results identical to DPN-diaphorase, Fig. $3 \mathrm{c}$ ), malic dehydrogenase, glutamate dehydrogenase (Fig. $3 \mathrm{~b}$ ), succinic dehydrogenase (Fig. 3a), TPN-diaphorase, glucose-6-phosphate dehydrogenase (Fig. $3 \mathrm{f}$ ), alcohol dehydrogenase (Fig. $3 \mathrm{~g}$ ), cytochrome oxidase, glycerophosphate dehydrogenase (Fig. 3d), and isocitric dehydrogenase (Fig. 3e). The reactions for the first five enzymes 
listed permitted one to easily recognize both "normal" and swollen axons; for the other enzymes, the increased reaction was observed in the swollen portion of axons but the reaction was too weak to permit distinction of that part of the axon which was not swollen.

Sections for all the enzyme reactions were constantly agitated during incubation. The agitation occasionally caused axons to be loosened and displaced in the unfixed sections. It was

a
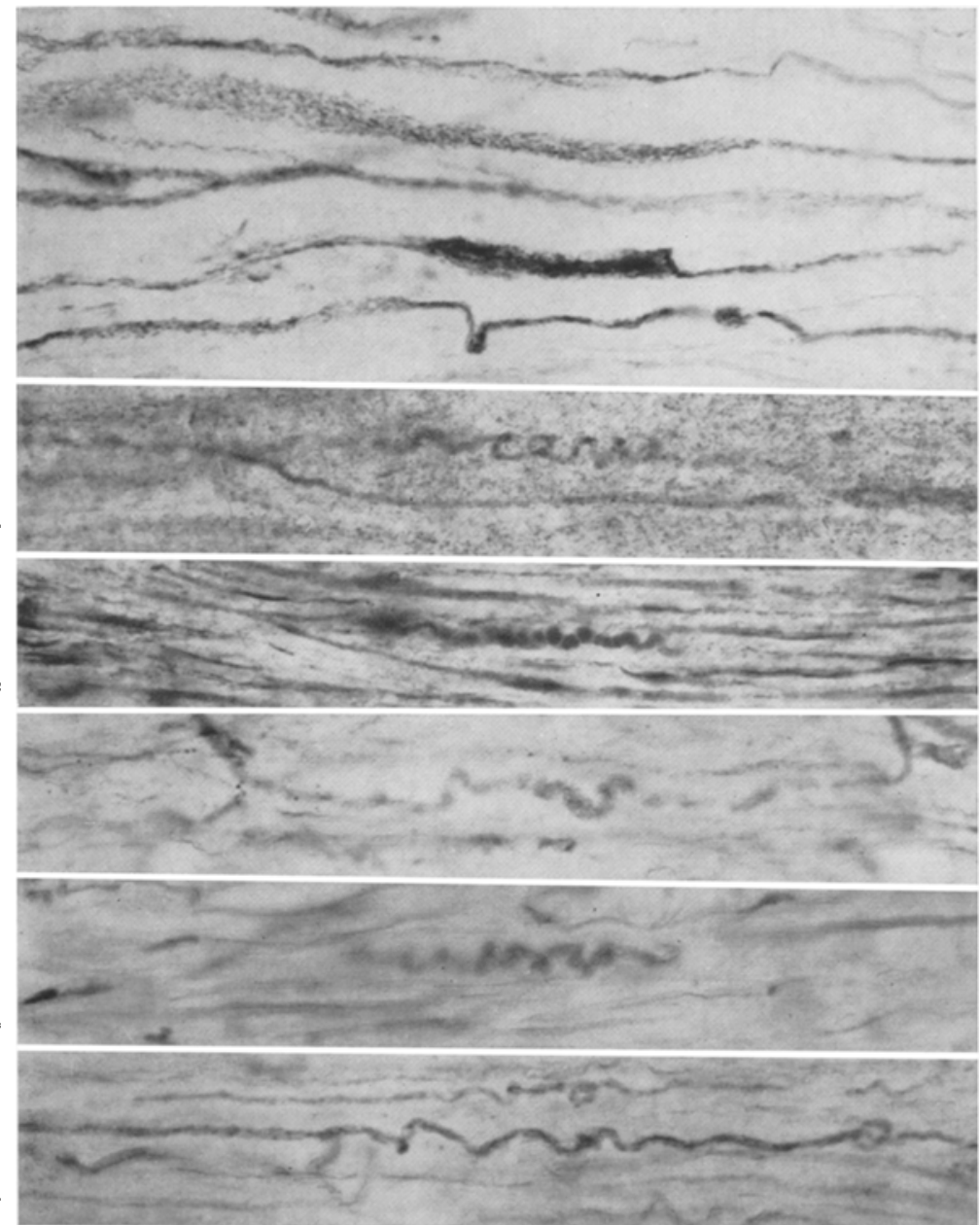

f

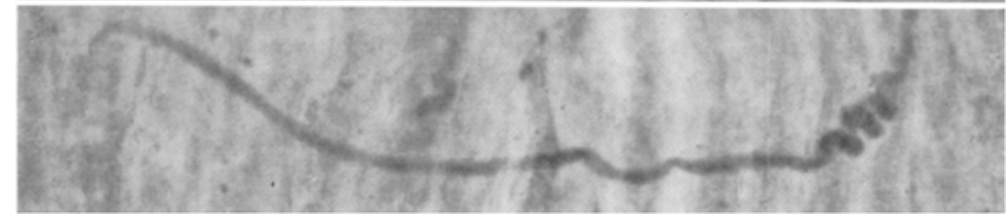

Fig. $3 \mathrm{a}-\mathrm{g}$. Comparative enzyme histochemistry of varicose axon swellings produced by electrophoresis. a succinic dehydrogenase, $250 \times$; b glutamate dehydrogenase, $250 \times$; c lactic dehydrogenase, $250 \times$; d glycerophosphate dehydrogenase, $250 \times$; e isocitric dehydrogenase, $350 \times$; f glucose-6-phosphate dehydrogenase, $250 \times$; and g alcohol dehydrogenase, $30 \mu 300 \times$

interesting to note that these axons retained their typical varicose or corkscrew shape even when displaced from the surrounding tissue (Fig. $3 \mathrm{~g}$ ); thus, mechanical compression of the tissue was not one of the mechanisms involved. 
Bodian's silver stain gave an excellent demonstration of the axonal swellings as well as "normal" fibers (Fig. 1a, e and e). The swellings usually showed a darker impregnation. This was paralleled by a marked alloxan-Schiff reaction for proteins (Fig. 4 a), and a marked periodic acid Schiff reaction for carbohydrate groups (Fig.4b) in the swollen axon stumps. There was a faint staining of swollen axons with chromalum gallocyanin (Fig.4b); but in adjacent sections, which had been treated with ribonuclease, the swollen axons were not stained. This indicated accumulation of ribonucleic acid in electrophoretic axon swellings.

There were numerous mitochondria in the club-shaped axon swellings and fewer in the varicose deformations; no mitochondria were distinguishable in "normal" axons. This gradient of distribution was in keeping both with electromicroscopical data 46 and with the distribution of several oxidative enzymes, particularly succinic dehydrogenase and cytochrome oxidase ${ }^{6}$ which are almost exclusively localized in mitochondria. In Sudan-black stained sections, only

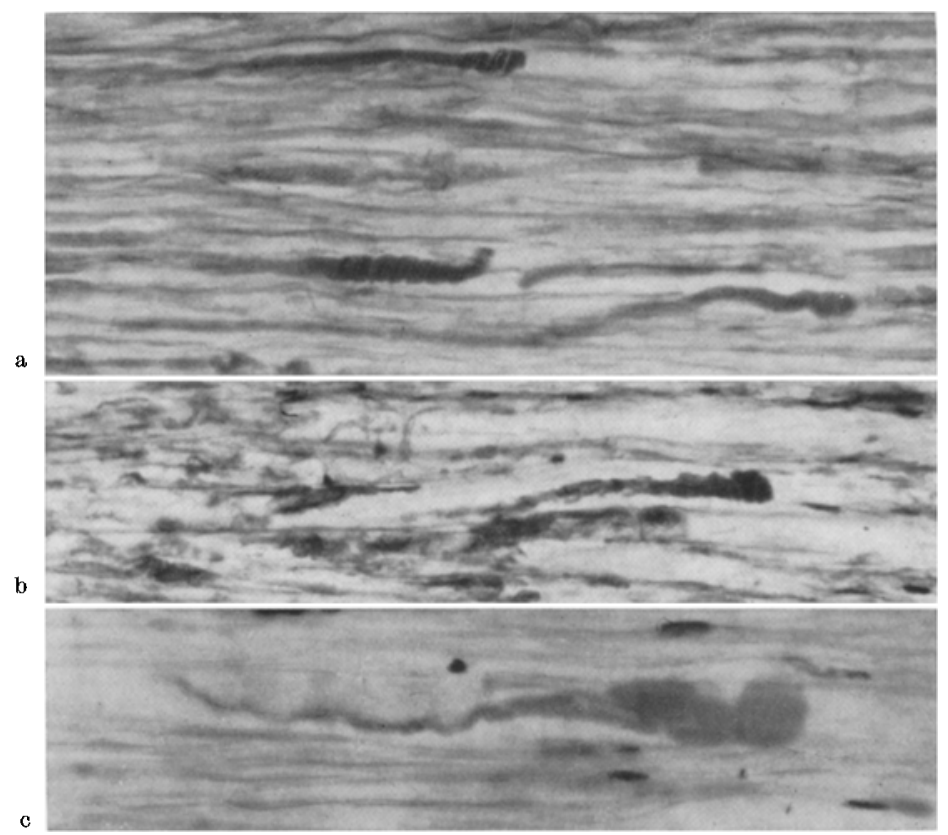

Fig. 4a-c. Comparative histochemistry of electrophoretically produced axon swellings. a alloxan-Schiff, $200 \times$; b periodic acid-Schiff, $200 \times$; c chromalum gallocyanin, $10 \mu 300 \times$

very large axon swellings could be identified by their typical shape and thus distinguished from the myelin sheaths or their fragments. Such swellings showed a granular staining with Sudanblack; it was assumed that the granularity could have been staining of the lipid membranes of mitochondria. The reactions for acid and alkaline phosphatase were never demonstrated in swollen axons.

Certainly, this data has proven the fallacy of the assumption that damming and accumulation of a substance in a swollen axon implied a changed rate of synthesis by the nerve cell. The nerve segments used measured about $4-5 \mathrm{~cm}$ and had no connection with nerve cells. Yet, there was sufficient material in these segments to produce a strong reaction for various axoplasmic constituents in the swellings. Moreover, data from multiple blows or multiple constrictions strongly suggested that only a few millimeters of axon contained sufficient material to account for the accumulation of various enzymes and other substances in the swellings. Thus, accumulation in a nerve stump may reflect only a local shift of the distribution of axoplasm. The axoplasm of normal fibers seems to be in a rather precarious state of uniform distribution. 


\section{Part II: Electrophoretic Behavior of Axoplasm in Reactive Axon Swellings Produced in Vivo}

The purpose of the second part of the investigation was to show that the axoplasma of reactive swellings that had been produced in vivo responded to electrophoresis in the same way as normal axoplasm. In $18 \mathrm{cats}$, the sciatic nerve was constricted with a tight ligature identical to that used for the in vitro experiments. Seven animals were killed after 3 days, the rest after

a

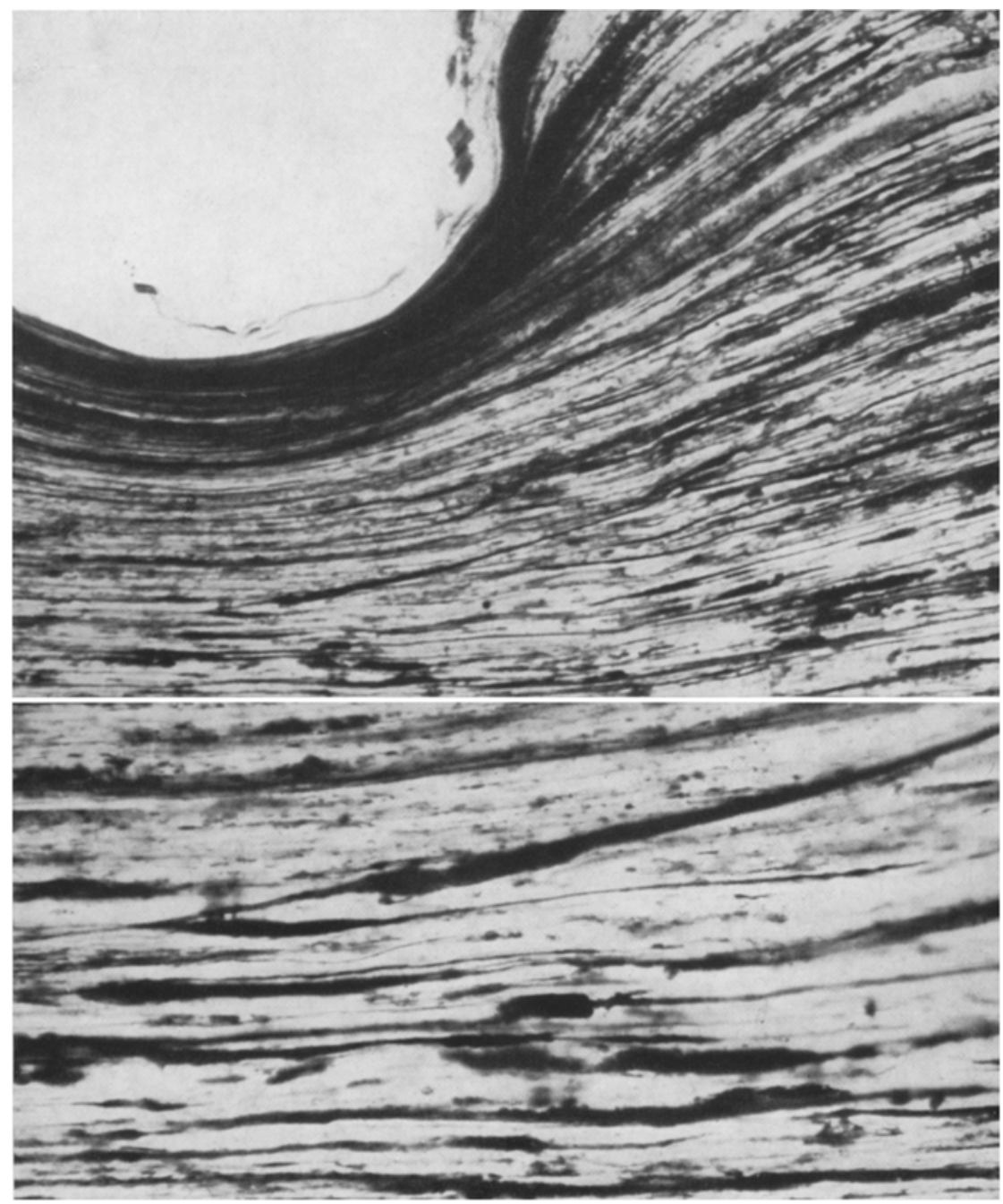

Fig.5. a Nlectrophoresis of axoplasm from axon swellings produced in vivo by ligation of the nerve. Formation of axon, swellings within the eonstricted portion, DPN-diaphorase, $60 \times$. b High power enlargement of same field, $30 \mu 200 \times$

4 days. The ligated nerves were removed as quickly as possible and exposed to a longitudinal current, all conditions being the same as described in "Materials and Methods".

Normally, such ligated nerve showed marked swelling of fibers and damming of enzyme activity ${ }^{6}$ immediately proximal to the site of constriction. Some swollen fibers with a strong enzyme reaction were also seen on the distal side of the constriction ${ }^{41}$. The significance of these changes in the distal portion will be subject to detailed studies in a subsequent paper. 
When such ligated nerves were exposed to a longitudinal current with distal end at the cathode, enzyme activity and axon swellings from the proximal side of the constriction moved, in a broad front, further proximal away from the constriction. If the distal end was at the anode, the swellings from the proximal side of the constriction moved farther into and distally beyond the constriction site. It was of particular interest that during electrophoresis with distal end at the anode, there was the regular development of axon swellings within the constricted portion of the nerve, even at the site of maximal compression (Fig.5) where they were never found if current had not been applied. This demonstrated that axoplasm had been electrophoretically conveyed into the compressed portion of the axons.

Not all the histochemical methods used in Part I were applied to this material; however, results identical to those in Part I were obtained with the methods for DPN-diaphorase, Bodian's silver stain, the periodic acid-Schiff reaction, and the alloxan-Schiff reaction.

These observations were considered evidence that the electrophoretic response of axoplasm and enzymes of in vivo reactive axon swellings was not significantly different from the response of axoplasm in normal nerves.

\section{Diseussion}

Exposure of nerve fibers to a longitudinal current produced axon swellings which were morphologically and histochemically indistinguishable from typical reactive axonal changes in pathological material. The production of such axon swellings depended both on an adequate electrical force and the presence of a local damage to the fiber. Given an adequate force (100 volts), changes indistinguishable from those in pathological material were produced within $2 \mathrm{hrs}$. In pathological material, the same extent of swelling develops, usually in $3-5$ days.

Electrophoretic convection produced inflation of the axons and damming at the site of an injury of a great number of axoplasmic constituents including: protein, carbohydrates, ribonucleic acid, lipids, mitochondria, a number of oxidative enzymes including TPN-diaphorase, DPN-diaphorase, succinic dehydrogenase, glycero-phosphate dehydrogenase, 6-phosphogluconic dehydrogenase, isocitric dehydrogenase, and glutamate dehydrogenase. Therefore, it can be assumed that most or all components of the axoplasma were subject to electrophoretic convection, at least in the state of molecular binding in which they normally exist in axoplasm.

When nerves with in vivo produced swollen axons were subjected to electrophoresis, the axoplasm in the swellings responded in the same way that axoplasm in fibers from normal nerves did.

It is of historical interest to quote a number of papers published during the first half of the century which dealt with the influence of longitudinal electrical polarization on the stainability of the nerve near the electrodes $2,3,17,31,33,36,37$. Several of these reports include observations of an increase of axonal diameter toward one of the polarizing electrodes $17,36,37$, but only SEEMAN ${ }^{37}$ mentioned, briefly, typical axonal deformations such as described in this paper.

Our experimental data could be compared with the histochemistry of axon swellings observed in a variety of neuropathological studies. Although this was actually part of our investigation, it was not reported in detail because these findings have been described in several other publications. Axon swellings in experimental material, as well as in a variety of neuropathological conditions, have shown an accumulation of succinic dehydrogenase, DPN-diaphorase, TPNdiaphorase ${ }^{6-8}$. Likewise, there are reports of accumulations of mitochondria ${ }^{45}$, 
increased reaction for proteins with the ninhydrin-Schiff method ${ }^{6}$, and positive reaction with periodic acid-Schiff and Sudan-black ${ }^{35}$. In contrast, acid and alkaline phosphatase were not increased in axon swellings ${ }^{13,24}$, which agrees with our in vitro findings.

In summary, it is concluded that the electrophoretically produced axon swellings were morphologically and histochemically indistinguishable from reactive axonal changes in vivo. Also, axoplasm in true reactive swellings (produced in vivo) showed the same response to electrophoresis as axoplasm in normal axons. The very strong currents used permitted one to produce axonal swellings within $1-2 \mathrm{hrs}$. The interval in which the same extent of swelling develops in vivo is $50-100$ times longer. These observations suggested that much weaker physiological currents in the tissue may represent the force responsible for the production of reactive axonal swellings as well as for the normal convection of axoplasm. Three sources of physiological currents deserve particular consideration as possible forces responsible for the development of axonal swellings.

1. The injury currents between damaged, depolarized, and the intact portions of a nerve.

2. The longitudinal current, in the axon, associated with the normal propagation of the action potential ${ }^{14-16}$; the latter deserves consideration also as a possible force responsible for the normal convection of axoplasm.

3. A longitudinal direct current gradient in nerves ${ }^{1}$.

Conceivably, all three factors could interact in the stumps of a severed nerve. A clear definition of the problems, thus, was indispensable for the design of further experiments which will attempt to elucidate the factors involved.

\section{Summary}

Application of a longitudinal current to fresh unfixed nerves produced, in $2 \mathrm{hrs}$, various types of axon swellings which were indistinguishable from reactive axon swellings in pathological material. Production of these swellings depended on an adequate time of exposure, an adequate current, and a local injury to the fiber.

In electrophoretically produced axon swellings, many oxidative enzymes accumulated such as: DPN-diaphorase, TPN-diaphorase, cytochrome oxidase, succinic dehydrogenase, lactic dehydrogenase, isocitric dehydrogenase, malic dehydrogenase, glutamate dehydrogenase, and alcohol dehydrogenase. Alkaline and acid phosphatase did not accumulate in axonal swellings. There was also an accumulation of mitochondria, lipids (probably in mitochondrial membranes), proteins, carbohydrates, and ribonucleic acid. This array of substances was identical with that found in reactive axonal swellings produced both experimentally and pathologically in vivo.

Axoplasm in reactive axon swellings that were produced in vivo showed the same electrophoretic convection as axoplasm of normal fibers.

Accumulation of substances in an axon swelling can result from a confined local shift of axoplasm; it does not inherently indicate a changed rate of production by the nerve cell.

Physiological currents in the tissue may well be responsible for the development of "reactive" axon swellings, as well as for the normal convection of axoplasm. 


\section{Zusammenfassung}

Die Anwendung von Längsdurchströmung auf frische, unfixierte Nerven erzeugt nach 2 Std verschiedene Arten von Axonschwellungen, welche von reaktiven Axonschwellungen in pathologischem Material nicht unterscheidbar sind. Die Erzeugung dieser Schwellungen hängt von der adäquaten Zeit des Stromdurchflusses, von adäquaten Stromkonstanten und von der lokalen Schädigung der Faser ab.

In den elektrophoretisch erzeugten Axonschwellungen häufen sich viele oxydative Enzyme an: so DPN-Diaphorase, TPN-Diaphorase, Cytochrom-Oxydase, Bernsteinsäure-Dehydrogenase, Milchsäure-Dehydrogenase, Isocitronensäure-Dehydrogenase, Äpfelsäure-Dehydrogenase, Glutamat-Dehydrogenase und AlkoholDehydrogenase. Alkalische und saure Phosphatase waren in den Axonschwellungen nicht vermehrt. Ebenso wird eine Anhäufung von Mitochondrien sowie von Lipoiden (wahrscheinlich in Mitochondrienmembranen), Proteinen, Kohlenhydrat und Ribonucleinsäure festgestellt. Diese Gruppierung von Substanzen ist identisch mit jener, die in reaktiven Axonschwellungen sowohl im Experiment als auch unter pathologischen Bedingungen in vivo gefunden wird.

Das Axoplasma von intravital erzeugten Axonschwellungen besitzt die gleiche elektrophoretische Mobilität wie das Axoplasma normaler Nervenfasern.

Die Substanzanhäufung in Axonschwellungen kann von einer lokal begrenzten Axoplasmaströmung herrühren; sie weist nicht unbedingt auf eine geänderte Produktionsrate in der Nervenzelle bin.

Physiologische Ströme im Gewebe können ebenso für die Entstehung von ,,reaktiven" Axonschwellungen wie für die normale Axoplasmaströmung verantwortlich gemacht werden.

\section{References}

1 BeCker, R. O., C. H. Bachuan and W. H. Sladghter: Longitudinal direct-current gradients of spinal nerves. Nature (Lond.) 196, 675-676 (1962).

2 BETHE, A.; Utber die Natur der Polarisationsbilder, welche durch den konstanten Strom am Nerven hervorgerufen werden können. Z. Biol. 62, 146-152 (1909).

3 - Nervenpolarisationsbilder und Erregungstheorie. Pflügers Arch. ges. Physiol. 183, 28 bis $302(1920)$.

1 Ramon y CaJaL, S.: Degeneration and regeneration of the nervous system, p. 1928. R. M. MAY (trans., and ed.). New York: Hafner Publ. Co. 1959.

5 Droz, B., and C. P. LeBLond: Migration of proteins along the axons of the sciatic nerve. Science 137, 1047-1048 (1962).

${ }^{6}$ FrIEDE, R. L.: Transport of oxidative enzymes in nerve fibers; a histochemical investigation of the regenerative cycle in neurons. Exp. Neuro]. 1, 441-466 (1959).

7 - Enzyme histochemical studies in multiple sclerosis. Arch. Neurol (Chic.) 5, 433-443 (1961).

8 - An enzyme histochemical study of cerebral arteriosclerosis; with some data on the pathogenesis of periarterial scars. Acta neuropath. (Berl.) 2, 58-72 (1962).

- L. M. Flemng and M. KNolder: A quantitative appraisal of enzyme histochemical methods in brain tissue. J. Histochem. Cytochem. 11, 232-245 (1963).

${ }^{10}$ GeraRd, R. W.: Nerve metabolism. Physiol. Rev. 12, 469-592 (1932).

11 HEBB, C., and A. SILVER: Gradient of cholinesterase activity and of choline acetylase activity in nerve fibers; gradient of choline aeetylase activity. Nature (Lond.) 189, 123-125 (1961).

12 -, and G. WALTHES: Choline acetylase in antero- and retro-grade degeneration of a cholinergic nerve. J. Physiol. (Lond.) 132, 667-671 (1956). 
${ }^{13}$ HeINzen, B.: Acid phosphatase activity in transected sciatic nerve. Anat. Rec. 98, 193-207 (1949).

${ }^{14}$ Hodler, J., R. StÄMrfluI and I. TASAKI: Role of potential wave spreading along myelinated nerve fiber in excitation and conduction. Amer. J. Physiol. 170, 375-389 (1952).

15 HuxLey, A. F., and R. StÄMPfLI: Evidence for saltatory conduction in peripheral myelinated nerve fibers. J. Physiol. (Lond.) 108, 315-339 (1949).

16 - - Saltatory transmission of the nervous impulse. Arch. Sci. Physiol. 3, 435-447 (1949).

17 Katsura, S.: Utber Wirkungen des konstanten Stroms auf das mikroskopische Bild des Nerven. Pflügers Arch. ges. Physiol. 217, 279-292 (1927).

${ }^{18}$ Konnta, H.: The synthesis and peripheral flow of axoplasm. Trans. Amer. Neurol. Ass. 88, $162-164$ (1928).

19 KonNT, E., and G. B. Koelde: Mode of regeneration of acetylcholinesterase in cholinergic neurons following irreversible inactivation. J. Neurochem. 8, 169-188 (1961).

${ }^{20}$ LaJtha, A.: Protein metabolism in nerve. In: Chemical pathology of the nervous system (J. Folch-Pr, ed.), p. 268-276. Pergamon Press 1961.

21 Lewis, P. R., and A. F. W. Hughes: The cholinesterase of developing neurones in Xenopus laevis, p. 511-514. In: Metabolism of the nervous system (Derek Richter ed.), p. 511-514. Pergamon Press 1957.

${ }^{22}$ LUBRKSKA, L., S. NIEMIERTKO and B. ODEREELD: Gradient of cholinesterase activity and of choline acetylase activity in nerve fibers; gradient of cholinesterase activity. Nature (Lond.) 189, 123-125 (1961).

23 _ _ $\ldots$ and L. SzWARK: Decrease of acetylcholinesterase activity along peripheral nerves. Science 135, 368-370 (1962).

24 Marchart, J.: Alkaline phosphatase activity in normal and degenerating peripheral nerves of the rabbit. J. Anat. (Lond.) 83, 229-237 (1949).

25 MIANI, N. : Evidence of proximo-distal movement along the axon of phospholipid synthetized in the nerve cell body. Nature (Lond.) 193, 887-888 (1962).

${ }^{26}$ Novelur, A.: A short method for chondriome. J. Histochem. Cytochem. 10, 102-103 (1962).

${ }^{27}$ OCHS, S., and E. BURGER: Movement of substance proximo-distally in nerve axons as studied with spinal cord injections of radioactive phosphorus. Amer. J. Physiol. 194, $499-506$ (1958).

28 - D. Datryirple and G. RichaRds: Axoplasmic flow in ventral root nerve fibers of the cat.

Exp. Neurol. 5, 349-363 (1962).

29 - R. Kachiann and W. E. DeMyer: Axoplasmic flow rates during nerve regeneration. Exp. Neuro]. 2, 627-637 (1960).

${ }^{30}$ Pearse, A. G. E.: Histochemistry: Theoretical and applied. Second Ed. Boston: Little, Brown, and Co. 1961.

${ }^{31}$ Rownke, F.: Über Elektrolytegehalt und elementare Zusammensetzung des Froschnerven in dem Verlauf der Leitungsstrecke und ihre Veränderungen mit der Reizung. Biochem. Z. 227, 715-726 (1931).

32 Samuels, A. J., L. L. Boyarsky, R. W. Gerard, B. Libet and M. Brunt: Distribution exchange and migration of phosphate compounds in the nervous system. Amer. J. Physiol. $164,1-15(1951)$.

${ }^{33} \mathrm{SATO}, \mathrm{K}$. : On the influence of electric polarization upon the stajnability of nerve. Folia anat. jap. 7, 33-43 (1929).

${ }^{34}$ SAWYER, C. H.: Cholinesterases in degenerating and regenerating peripheral nerves. Amer. J. Physiol, 146, 246-253 (1946).

${ }^{35}$ Schlote, W.: Morphologische und histochemische Untersuchungen an retrograden Axonveränderungen im Zentralnervensystem. Acta neuropath. (Berl.) 1, 135-158 (1961).

${ }^{36}$ SCHWARtZ, A.: Über die Beeinflussung der primären Färbbarkeit und der Leitungsfähigkeit des polarisierten Nerven durch die den Strom zuführenden Ionen. Pflügers Arch. ges. Physiol. 138, 487-524 (1911).

${ }^{37}$ Semman, J.: Über die Bedeutung der Färbbarkeitsänderung tierischer Gewebe durch elektrische Polarisation. Z. Biol. 53, 287-302 (1909).

38 SNeLL, R. S.: Changes in the histochemical appearances of cholinesterase in a mixed peripheral nerve following nerve section and compression injury. Brit. J. exp. Path. 38, $479-482$ (1957). 
228 REINHARD L. FRIEDE: Electrophoretic production of "reactive" axon swellings

${ }^{39}$ WAELSCH, H.: Some aspects of amino acid and protein metabolism of the nervous system. J. nerv. ment. Dis. 126, 33-39 (1958).

${ }^{40}$ WEISS, P.: Endoneurial edema in constricted nerve. Anat. Rec. 86, 491-522 (1943).

41 - Damming of axoplasm in constricted nerve: A sign of perpetual growth in nerve fibers. Anat. Rec. 88, 464-465 (1944).

42 - Evidence of perpetual proximo-distal growth of nerve fibers. Biol. Bull. 87, 160 (1944).

43 - The concept of perpetual neuronal growth and proximodistal-substance convection. In: Regional Neurochemistry (S. S. KETX and J.EukEs, єd.), p. 220-242. Pergamon Press 1961 .

44 -, and H. B. Hiscos: Experiments on the mechanism of nerve growth. J. exp. Zool. 107, $315-395$ (1948).

15 - C. TAYLOR and P. Pillat: The nerve fiber as a system in continuous flow: Microcinematographic and electromicroscopic demonstrations. Science 136, 330 (1962).

46 - H. WANG, A. C. TAYLOR and M. V. EDds jr.: Proximo-distal fluid convection in the endoneurial spaces of peripheral nerves, demonstrated by colored and radioactive (isotope) tracers. Amer. J. Physiol. 143, 521-540 (1945).

47 Young, J. Z.: Contraction, turgor, and the cytoskeleton of nerve fibers. Nature (Lond.) 153, $333-335$ (1944).

${ }^{48}$ YUIEN, K., and K. SATo: On the spreading path of stains injected into the nerve. Folia anat. Jap. 7, 419-423 (1929).

49 ZELENÁ, J., and L. LuBcísKa: Early changes of acetylcholinesterase activity near the lesion in crushed nerves. Physiol. bohemoslov. 11, 261-268 (1962).

Dr. Reinhard L. Frifide M. D., Associate Professor of Pathology,

Mental Health Research Institute, Department of Psychiatry, The University of Michigan, Ann Arbor/Michigan, United States 